\title{
ANALISIS PENERAPAN KESELAMATAN KERJA DALAM UPAYA PENGENDALIAN KECELAKAAN KERJA DI PT. BUDI DWIYASA PERKASA
}

\author{
Riana Septiani, Prayogo \\ Program Studi Teknik Industri Fakultas Teknik \\ Universitas Tulang Bawang Lampung
}

\begin{abstract}
In conducting activities, many found workers who did not use personal protective equipment, do not pay attention to safety in work and work done like without procedure. PT. Budi Dwiyasa Perkasais a plantation company palm oil. Based on accident data obtained work, there are 14 case of accident in April until June 2016 in PT. Budi Dwiyasa Perkasa. A major factor cause of the accident is unsafe actions and unsafe conditions. Hazard analysis needs to be done in order to prevent the accident of work.

Hazard identification done with using the risk assessment method. This analysis of the technique used to determine the level of the risk of a job is a combination of between

the possibility of the harms caused by the severity of the caused. The result of hazard identification with this method is used in a kind of work to have a high risk level and need to address special in order to prevent the accident.
\end{abstract}

Keywords: safety, accident, risk, hazard identification,

\section{Pendahuluan}

Memasuki dunia industri yang semakin modern yang diikuti oleh penerapan teknologi tinggi, penggunaan bahan dan peralatan makin kompleks dan rumit, tenaga kerja yang semakin ahli dan terampil. Namun tidak selamanya penerapan teknilogi tinggi dan penggunaan bahan yang beraneka ragam dalam suatu industri diikuti dengan selaras oleh keterampilan tenaga kerja yang mengoperasikan peralatan dan menggunakan bahan dalam proses industri tersebut. Suatu kemungkinan bahaya yang besar berupa kecelakaan, peledakan, kebakaran, pencemaran lingkungan dan penyakit akibat kerja dapat diakibatkan oleh kesalahan dalam penggunaan peralatan, pemahaman dan keterampilan tenaga kerja yang kurang memadai.
PT. Budi Dwiyasa Perkasa merupakan perusahaan yang bergerak dibidang perkebunan kelapa sawit yang berlokasi di Way Serdang Kabupaten Mesuji Provinsi Lampung.Luas area perkebunan PT. Budi Dwiyasa Perkasa lebih dari 5.000 hektare. Aktivitas pekerjaan yang dilakukan di perusahaan ini adalah perawatan dan pemanenan. Kegiatan perawatan antara lain pemupukan, pembersihan tumbuhan liar di sekitar pohon kelapa sawit dan pembersihan pelepah kelapa sawit yang sudah kering. Sedangkan kegiatan pemanenan adalah memetik buah sawit dengan menggunakan alat bantu atau sering disebut "dodos". Dalam melakukan aktivitas, banyak didapati pekerja yang tidak menggunakan alat pelindung diri, tidak memperhatikan keselamatan dalam 
bekerja, dan pekerjaan yang dilakukan seperti tanpa prosedur standar.

Dalam melakukan penyemprotan insektisida, pekerja tidak menggunakan sarung tangan dan masker.Kegiatan penyemprotan tanpa menggunakan alat pelindung diri sangat berisiko terhadap kesehatan.Pekerja dapat terpapar insektisida yang disemprotkan. Sama halnya kegiatan yang dilakukan pada saat pemanenan buah sawit.Pekerja tidak menggunakan sarung tangan dan helm pada saat memetik buah sawit.

Aktivitas tersebut berlangsung berulang-ulang dan sudah menjadi budaya dalam bekerja.Tidak sedikit kecelakaan yang terjadi, mulai dari tersayat pelepah sawit sampai dengan tertimpa tandan buah sawit.Sampai dengan semester satu tahun 2016, angka kecelakaan kerja hampir mencapai angka 50 kasus. Untuk memperbaiki kondisi tersebut, perlu dilakukan sosialisasi dan pemahaman akan pentingnya bekerja aman dan selamat. Analisis keselamatan kerja perlu dilakukan di tempat kerja.Hasil analisis tersebut dapat digunakan untuk menghilangkan dan mencegah bahaya di area kerja.Dalam hal ini, penulis mencoba untuk melakukan analisis keselamatan kerja pada PT. Budi Dwiyasa Perkasa dalam upaya pencegahan 
Tabel 1. Data Kecelakaan Kerja Bulan April Juni 2016 PT. BDP

\begin{tabular}{|c|c|c|c|c|c|}
\hline No & Nama & Umur & Keparahan & Kerugian & $\begin{array}{c}\text { Sebab } \\
\text { Kecelakaan }\end{array}$ \\
\hline 1 & $\begin{array}{l}\text { Saim } \\
\text { in }\end{array}$ & 38 & $\begin{array}{l}\text { Luka pada } \\
\text { lengan kiri } \\
\text { bagian } \\
\text { bawah } \\
(\mathrm{STMB})\end{array}$ & 8 hari & $\begin{array}{l}\text { Kejatuhan } \\
\text { egrek saat } \\
\text { melakukan } \\
\text { kegiatan } \\
\text { pemangkasan }\end{array}$ \\
\hline 2 & $\begin{array}{l}\text { Saud } \\
\mathrm{i}\end{array}$ & 28 & $\begin{array}{l}\text { Luka pada } \\
\text { kuku (CR) }\end{array}$ & - & $\begin{array}{l}\text { Tersayat mata } \\
\text { egrek saat } \\
\text { diasah }\end{array}$ \\
\hline 3 & $\begin{array}{l}\text { Syari } \\
\text { pudi } \\
\mathrm{n}\end{array}$ & 25 & $\begin{array}{l}\text { Luka pada } \\
\text { tangan } \\
(\mathrm{CR})\end{array}$ & - & $\begin{array}{l}\text { Kejatuhan } \\
\text { pelepah saat } \\
\text { panen }\end{array}$ \\
\hline 4 & $\begin{array}{l}\text { Pung } \\
\text { ut }\end{array}$ & 52 & $\begin{array}{l}\text { Luka pada } \\
\text { jempol kaki } \\
(\mathrm{CR})\end{array}$ & - & $\begin{array}{l}\text { Kaki } \\
\text { menyandung } \\
\text { pelepah }\end{array}$ \\
\hline 5 & $\begin{array}{l}\text { Unan } \\
\mathrm{g} \\
\text { Rus } \\
\text { mana }\end{array}$ & 36 & $\begin{array}{l}\text { Luka pada } \\
\text { tangan } \\
(\mathrm{CR})\end{array}$ & - & $\begin{array}{l}\text { Kejatuhan } \\
\text { pelepah saat } \\
\text { panen }\end{array}$ \\
\hline 6 & $\begin{array}{l}\text { Suna } \\
\text { rto }\end{array}$ & 43 & $\begin{array}{l}\text { Luka pada } \\
\text { bahu (CR) }\end{array}$ & - & $\begin{array}{l}\text { Kejatuhan } \\
\text { pelepah saat } \\
\text { melakukan } \\
\text { kegiatan } \\
\text { pemangkasan }\end{array}$ \\
\hline 7 & $\begin{array}{l}\text { Juard } \\
\mathrm{i}\end{array}$ & 50 & $\begin{array}{l}\text { Luka pada } \\
\text { mata (CR) }\end{array}$ & - & $\begin{array}{l}\text { Mata } \\
\text { kejatuhan } \\
\text { kotoran } \\
\text { pelepah sawit }\end{array}$ \\
\hline 8 & $\begin{array}{l}\text { Wari } \\
\text { s } \\
\text { Iraw } \\
\text { an } \\
\end{array}$ & 32 & $\begin{array}{l}\text { Luka pada } \\
\text { muka/waja } \\
\text { h (STMB) }\end{array}$ & 3 hari & $\begin{array}{l}\text { Kejatuhan } \\
\text { pelepah saat } \\
\text { panen }\end{array}$ \\
\hline 9 & $\begin{array}{l}\text { Edi } \\
\text { Muly } \\
\text { ono }\end{array}$ & 22 & $\begin{array}{l}\text { Luka pada } \\
\text { kaki } \\
(\mathrm{STMB})\end{array}$ & 2 hari & $\begin{array}{lr}\text { Tersayat } & \text { besi } \\
\text { plat } & \text { titian } \\
\text { kanal } & \text { saat } \\
\text { panen } & \\
\end{array}$ \\
\hline 10 & $\begin{array}{l}\text { Ulul } \\
\text { Amri }\end{array}$ & 31 & $\begin{array}{l}\text { Luka pada } \\
\text { kaki } \\
\text { (STMB) }\end{array}$ & 10 hari & $\begin{array}{l}\text { Terkena } \\
\text { serpihan } \\
\text { kerikil saat } \\
\text { memotong } \\
\text { rumput } \\
\text { dengan mesin }\end{array}$ \\
\hline 11 & $\begin{array}{l}\text { Wina } \\
\text { rto }\end{array}$ & 32 & $\begin{array}{l}\text { Luka pada } \\
\text { lengan } \\
\text { (STMB) }\end{array}$ & 2 hari & $\begin{array}{l}\text { Lengan } \\
\text { tertusuk duri } \\
\text { pelepah sawit }\end{array}$ \\
\hline 12 & $\begin{array}{l}\text { Eko } \\
\text { Purw } \\
\text { anto } \\
\end{array}$ & 40 & $\begin{array}{l}\text { Luka pada } \\
\text { tangan kiri } \\
\text { (STMB) }\end{array}$ & 3 hari & $\begin{array}{l}\text { Tersayat sabit } \\
\text { saat babat } \\
\text { rumput }\end{array}$ \\
\hline 13 & $\begin{array}{l}\text { Juwa } \\
\text { ri }\end{array}$ & 23 & $\begin{array}{l}\text { Luka pada } \\
\text { lutut kiri } \\
(\mathrm{STMB})\end{array}$ & 2 hari & $\begin{array}{l}\text { Jatuh dari } \\
\text { motor saat } \\
\text { berangkat } \\
\text { kerja }\end{array}$ \\
\hline 14 & $\begin{array}{l}\text { Kirsa } \\
\mathrm{n}\end{array}$ & 47 & $\begin{array}{l}\text { Luka pada } \\
\text { tangan } \\
\text { (STMB) }\end{array}$ & - & $\begin{array}{l}\text { Kejatuhan } \\
\text { pelepah sawit }\end{array}$ \\
\hline
\end{tabular}

Keterangan :

STMB $=$ Sementara Tidak Mampu Bekerja

$\mathrm{CR}=$ Cidera Ringan

Egrek = alat pemanen sawit untuk pohon yang sudah tinggi $(>3 \mathrm{~m})$

Dodos = alat pemanen sawit untuk pohon yang rendah $(<3 \mathrm{~m})$

\section{Tinjauan Pustaka}

\section{Pengertian Kecelakaan Kerja}

Pengertian kecelakaan kerja berdasarkan Frank Bird Jr adalah kejadian yang tidak diinginkan yang terjadi dan menyebabkan kerugian pada manusia dan harta benda.

Berdasarkan McCormick Jr (1985)

kecelakaan adalah suatu kejadian atau peristiwa tidak terduga atau bertentangan dengan yang diharapkan pada suatu aktivitas proses produksi.

\section{Penyebab Kecelakaan Kerja}

Pada awalnya Heinrich dalam teori dominonya mengemukakan bahwa penyebab kecelakaan didasarkan atas kesalahan manusia sebanyak $88 \%$ kasus kecelakaan disebabkan perbuatan tidak aman, $10 \%$ disebabkan oleh kondisi tidak aman,dan $2 \%$ merupakan takdir dari Tuhan.

\section{Dampak Kecelakaan Kerja}

Terjadinya kecelakaan dapat menimbulkan kerugian berupa cedera atau kematian pada pekerja, harta benda, kerusakan lingkungan dan proses. Kerugian dapat menimpa diri pekerja dan keluarga, perusahaan, masyarakat, dan pemerintah (Imam Khasani, 1991).

Kerugian akibat suatu kecelakaan dapat berupa kerugian moril, yaitu penderitaan bagi si korban ataupun keluarganya, Korban sendiri disamping mengalami kesakitan apabila mengakibatkan luka, juga akan mengalami tekanan mental selama dirawat karena merasa dirinya tidak berguna atau tidak mampu berbuat sesuatu dan memerlukan bantuan orang lain. Disamping luka fisik atau jasmani, korban juga akan mengalami luka rohani atau mental, seperti tidak berani malakukan kembali pekerjaannya semula. 
Suatu kecelakaan tidak terjadi dengan sendirinya atau terjadi begitu saja, karena kecelakaan selalu ada sebabnya.Faktor penyebab kecelakaan pada umumnya tidak hanya satu faktor, tetapi merupakan rangkaian beberapa faktor yang saling berhubungan antara satu faktor dengan faktor yang lainnya, karena suatu kecelakaan merupakan hasil dari beberapa faktor yang saling berhubungan atau terdiri dari deretan faktor.Hal tersebut dikenal dengan teori domino.

Karena kecelakaan merupakan suatu hal merugikan, maka selalu diupayakan untuk dilakukan pencegahan.Pencegahan kecelakaan yang dilakukan sebelum terjadinya kecelakaan disebut sebagai upaya prospektif, dan upaya pencegahan yang dilakukansetelah terjadi kecelakaan disebut sebagai upaya retrospektif, yaitu dilakukan melalui analisis kecelakaan untuk dapat menemukan faktor penyebabnya.Dengan menemukan faktor penyebabnya maka dapat dilakukan pencegahan secara tepat agar kecelakaan serupa tidak terulang kembali.

\section{Metode Penelitian}

Penelitian ini bersifat kualitatif dan mengutamakan makna. Dan makna yang diungkap berkisar pada persepsi orang mengenai suatu peristiwa, misalnya penelitian tentang peran ahli $\mathrm{K} 3$ dalam melakukan pembinaan kepada tenaga kerja, peneliti memusatkan perhatian pada pendapat ahli K3 tentang tenaga kerja yang dibinanya.

Metode analisis data yang dilakukan berpedoman pada Undang-Undang Nomor 1 Tahun 1970 tentang Keselamatan Kerja dan Peraturan Pemerintah Nomor 50 Tahun 2012 tentang Penerapan Sistem Manajemen Keselamatan dan Kesehatan Kerja. Penulis juga menggunakan Peraturan Menteri Perburuhan Nomor PER.07/MEN/1964 tentang Syarat Kesehatan, Kebersihan serta Penerangan dalam Tempat Kerja.
Teknik analisa data yang digunakan dalam penelitian adalah penilaian tingkat risiko. Teknik analisa ini digunakan untuk menentukan tingkat risiko suatu pekerjaan yang merupakan kombinasi antara kemungkinan bahaya yang ditimbulkan dengan seberapa parah dampak yang diakibatkan dari bahaya/kecelakaan yang akan terjadi. Untuk variabel kemungkinan, dibagi menjadi tiga kategori, yaitu: tidak mungkin, mungkin dan sangat mungkin. Sedangkan variabel keparahan, dibagi menjadi tiga kategori yaitu: sedikit bahaya, bahaya dan sangat bahaya. Tabel penilaian tingkat risiko dapat dilihat pada tabel berikut

Tabel 1. Penilaian Tingkat Risiko

\begin{tabular}{|c|c|c|c|c|}
\hline \multirow{2}{*}{\multicolumn{2}{|c|}{$\begin{array}{c}\text { RISK = LIKELIHOOD X } \\
\text { SEVERITY }\end{array}$}} & \multicolumn{3}{|c|}{ SEVERTTY } \\
\hline & & SLIGTLYY HARMFUL (\$) & HARMFUL(H) & EXTREMELY HARMFUL (E) \\
\hline \multirow{6}{*}{$\begin{array}{l}8 \\
8 \\
0 \\
5 \\
y \\
y\end{array}$} & HGGLY UNLIKEYY (HU) & \multirow{2}{*}{ TRIIZALRISK } & \multirow{2}{*}{ TOLERABLE RISK } & \multirow{2}{*}{ MODERATE RISK } \\
\hline & NILAI $\leq 16$ & & & \\
\hline & UNLIKELY (UL) & \multirow{2}{*}{ TOLERABLE RISK } & \multirow{2}{*}{ MODERATE RISK } & \multirow{2}{*}{ SUBSTANTLAL RISK } \\
\hline & $16<\mathrm{NLAI}<51$ & & & \\
\hline & LIKELY (LK) & \multirow{2}{*}{ MODERATE RISK } & \multirow{2}{*}{ SUBSTANTLAL RISK } & \multirow{2}{*}{ INTOLERABLE RISK } \\
\hline & $51<\mathrm{NLAI} \leq 70$ & & & \\
\hline
\end{tabular}

Keterangan:

$\begin{array}{ll}\text { Risk } & =\text { Risiko } \\ \text { Trivial Risk } & =\text { Risiko Kecil/Sepele } \\ \text { Tolerable Risk } & =\text { Cukup Berisiko } \\ \text { Moderate Risk } & =\text { Risiko Sedang } \\ \text { Substantial Risk } & =\text { Risiko Besar } \\ \text { Intolerable Risk } & =\text { Risiko Sangat Besar } \\ \text { Likelihood } & =\text { Kemungkinan } \\ \text { Highly Unlikely } & =\text { Sangat Tidak Mungkin } \\ \text { Unlikely } & =\text { Tidak Mungkin } \\ \text { Likely } & =\text { Mungkin } \\ \text { Severity } & =\text { Keparahan } \\ \text { SlightlyHarmful } & =\text { Cukup Bahaya } \\ \text { Harmful } & =\text { Bahaya } \\ \text { ExtremelyHarmful } & =\text { Sangat Bahaya }\end{array}$

Ada beberapa faktor yang dijadikan parameter kemungkinan, seperti pada Tabel, antara lain:

a. Jumlah pekerja, menunjukkan jumlah pekerja yang terpapar oleh bahaya potensial;

b. Frekuensi dan lama paparan, menerangkan frekuensi dan lamanya 
paparan bahaya potensial kepada pekerja dalam durasi waktu harian, mingguan, bulanan, tahunan;

c. Proses produksi, menggambarkan proses produksi (oleh mesin dan/manusia) yang sedang berlangsung hingga menyebabkan proses produksi berhenti atau tidak menyebabkan proses produksi berhenti;

d. Pengaruh ke lingkungan, menerangkan paparan dari bahaya potensial kepada lingkungan di sekitar bahaya potensial tersebut;

e. Alat pelindung diri, bagaimana pemakaian APD oleh dan untuk pekerja;

f. Sejarah kecelakaan dan keluhan, menerangkan kejadian kecelakaan dan keluhan yang telah tercatat dan terekam;

Perundangan/persyaratan lainnya, menerangkan ada atau tidaknya persyaratan K3 yang terkait dengan cara dan tempat kerja.

Untuk variabel keparahan, dikategorikan menjadi tiga bagian, yaitu:

a. Tidak bahaya, meliputi : luka pada permukaan tubuh, tergores, terpotong kecil, memar, iritasi mata, bising, sakit kepala, ketidaknyamanan;

b. Bahaya, meliputi : luka terkoyak, terbakar, gegar otak, terkilir serius, patah tulang ringan, tuli, sakit/radang kulit, asma, cacat minor permanen;

c. Sangat bahaya, meliputi:amputasi, patah tulang berat, keracunan, luka kompleks, luka fatal, kanker, penyakit mematikan, penyakit fatal akut, kematian.

\section{Analisa dan Pembahasan}

\section{a. Kegiatan Perawatan Tanaman dan Pemanenan}

Kegiatan perawatan tanaman kelapa sawit meliputi pembersihan piringan, penunasan, pemupukan dan penyiangan
gulma.Pemeliharaan piringan dilakukan sebanyak tiga kali setahun dan umumnya disesuaikan dengan waktu pemupukan. Pembersihan area dilakukan dengan cara dibabat atau dikoret dan juga dengan penggunaan bahan kimia pembasmi gulma.

Penunasan dilakukan untuk mengatur jumlah pelepah yang perlu dipertahankan atau ditinggalkan di pohon karena berpengaruh terhadap pertumbuhan akar, bobot tandan dan produksi TBS (tandan buah sawit) meskipun tidak berpengaruh nyata terhadap jumlah tandan.Jumlah pelepah bila tanaman berumur $>8$ tahun adalah $40-48$ pelepah setiap pohon.Penunasan pada kebun dilakukan sekalu setahun.

Pemberian pupuk ditabur merata dalam piringan dengan jarak 1,5 meter dari batang pohon. Jumlah dan jenis penggunaan pupuk adalah : urea 1 $\mathrm{kg} /$ pokok, TSP $1 \mathrm{~kg} /$ pokok dan KCL 1 $\mathrm{kg} /$ pokok, diberikan dengan frekuensi $3 \mathrm{kali}$ setahun.

Tandan buah sawit yang cukup matang dipanen dengan cara manual menggunakan dodos dan pisau bergalah (egrek) dengan tenaga manusia. Buah yang layak panen adalah buah luar yang telah lepas dari tandan dan jatuh ke tanah (piringan) yang sering disebut brondolan.Buah dikatakan layak apabila sudah terdapat dua buah brondolan untuk tiap kg tandan dengan tandan yang beratnya $>10$ kg.kriteria umum tersebut adalah pencerminan dari tingkat kematangan tandan yang optimal yaitu matang atau disebut sebagai fraksi 1, 2 dan 3.

Pemanenan buah meliputi pemotongan pelepah, memotong tandan dari pohon, memotong gagang pohon tandan, megumpulkan brondolan, mengangkat tandan dan brondolan ke tempat penampungan hasil (TPH) serta memotong dan menyusun pelepah pada gawangan mati.Selanjutnya dilakukan pengangkutan TBS dari TPH ke pabrik 
pengolahan kelapa sawit menggunakan truk.

\section{b. Identifikasi Sumber Bahaya}

Identifikasi bahaya adalah dasar dari pengelolaan keselamatan kerja modern, yang didalam perusahaan program pengelolaan ini disusun berdasarkan tingkat risiko yang ada di lingkungan kerja.Dengan harapan dapat menghilangkan atau meminimalkan sampai batas yang dapat dan ditoleransi baik dari kaidah keilmuan maupun tuntutan hukum dari setiap bahaya yang ada dengan kondisi bagaimanapun.

Hasil identifikasi bahaya pada kegiatan perawatan tanaman adalah terpapar bahan kimia berbahaya pada saat pembasmian gulma.Pekerja tidak menggunakan sarung tangan dan masker pada saat melakukan kegiatan penyemprotan.Dalam melakukan pembersihan piringan, pekerja tidak memakai pelindung kaki.Besar kemungkinan terserang sengatan binatang beracun seperti ular dan sangat memungkinkan terkena cangkul ataupun tersayat tanaman gulma yang berduri.

Pada gudang penyimpanan pupuk tidak terdapat Lembar Data Keselamatan Bahan (LDKB).LDKB merupakan suatu berkas data yang mengandung informasi mengenai sifat-sifat suatu bahan.Lembar data ini bertujuan memberikan informasi kepada pekerja dan personel gawat darurat dalam penanganan suatu bahan dengan aman. Informasi yang diberikan seperti toksisitas, efek kesehatan, perawatan/penanganan pertama jika terkena bahan tersebut, reaktivitas, cara penyimpanan, peralatan pelindung yang diperlukan, dan prosedur penanganan bahan yang tumpah.

Hasil identifikasi bahaya pada kegiatan pemanenan adalah tertimpa buah sawit atau pelepah sawit.Pekerja tidak menggunakan pelindung kepala (safety helmet) pada saat kegiatan tersebut.Pekerja juga kurang memperhatikan posisi memetik terhadap arah jatuhnya buah.Saat memanen, pekerja tidak menggunakan kacamata pengaman (google glass).Serpihan buah atau pelepah berpotensi masuk ke mata.Pekerja hanya menggunakan sandal pada kegiatan pemanenan dan tidak menggunakan sarung tangan.

Peralatan panen seperti dodos, pisau bergala (egrek), golok dan sabit tidak bersarung saat dibawa ke tempat kerja. Peralatan tersebut dibawa menggunakan sepeda motor yang memungkinkan tersangkut pada ranting pohon dan membahayakan pengendara lain bilamana melintas.

Posisi mengangkat tandan buah sawit saat memindahkan ke lori tidak ergonomis, berpotensi cidera tulang punggung. Jembatan/titian untuk menyebrang lori melintasi kanal tidak aman. Kondisi tidak aman tersebut memungkinkan pekerja terjatuh ke kanal saat membawa lori yang bermuatan tandan buah sawit.

\section{Pembahasan}

Berdasarkan data identifikasi bahaya potensial dan penilaian risiko pada Tabel 4.1, aktifitas pekerjaan yang memiliki potensi bahaya sedang adalah :

a. Pemotongan pelepah sawit;

b. Pemberian pupuk;

c. Pemotongan tandan buah matang;

d. Pengangkutan hasil ke TPH.

Pemotongan pelepah sawit pada pekerjaan penunasan maupun pemanenan memiliki bahaya potensial fisik yaitu kejatuhan pelepah sawit.Bahaya potensial ini mempunyai nilai kemungkinan sebesar 52 dengan tingkat keparahan bahaya kecil tetapi menimbulkan risiko sedang. Bila melihat data kecelakaan kerja pada bulan April sampai dengan Juni, terdapat lima kasus kecelakaan kerja yang disebabkan oleh kejatuhan pelepah sawit. Hal-hal yang perlu diperhatikan pada aktifitas pemotongan pelepah sawit adalah 
memastikan arah jatuh pelepah menjauhi badan kita, pastikan tinggi egrek menjangkau pelepah yang akan dipotong dan gunakan alat pelindung diri berupa sarung tangan, google glass dan helmet.

Aktifitas pekerjaan lain yang mempunyai bahaya potensial tingkat risiko sedang adalah pemupukan. Pada kegiatan ini, aktifitas yang dilakukan adalah memberikan pupuk ke pohon sawit dengan bahaya potensial biologi terpatuk ular berbisa. Ular berbisa jenis cobra banyak ditemukan di perkebuanan sawit karena sengaja disebar untuk membasmi hama tikus yang akan merusak buah sawit. Halhal yang perlu diperhatikan dalam melakukan kegiatan ini adalah menggunakan safety boot untuk menghindari patukan ular. Selain itu dalam melakukan pemupukan harus menggunakan sarung tangan dan masker guna menghindari paparan bahan kimia dari pupuk tersebut.Pastikan mencuci tangan setelah melakukan pekerjaan ini dan biasakan mencuci tangan dengan sabun.

Aktifitas pemotongan tandan buah matang memiliki bahaya potensial fisik kejatuhan tandan buah. Total nilai kemungkinan pada aktifitas ini adalah 40 dengan tingkat keparahan kategori bahaya dan tingkat risiko sedang. Dalam melakukan aktifitas pemotongan tandan buah harus memperhatikan arah jatuhnya buah. Pastikan tinggi pisau dodos sesuai dengan tinggi buah yang akan dipotong, jangan terlalu tinggi ataupun terlalu rendah. Gunakan alat pelindung kepala, kacamata pelindung, sarung tangan dan safety boot saat melakukan kegiatan tersebut.

Aktifitas terakhir yang mempunyai bahaya potensial tingkat risiko sedang adalah pangangkutan buah ke tempat penampungan hasil (TPH).Aktifitas pengangkutan buah ke TPH, bahaya potensial berupa terpeleset di titian kanal, dengan tingkat keparahan kategori bahaya. Dalam kegiatan ini, sebelum tandan buah sawit (TBS) diangkut ke TPH, dikumpulkan dahulu di pinggir jalan dengan menyebrangi kanal selebar 2,5 meter sampai 3,5 meter. Titian yang digunakan untuk menyebrangi kanal berupa plat besi selebar lebih kurang $50 \mathrm{~cm}$. Kondisi tidak aman ini yang berpotensi terpeleset atau tergelincir pada saat membawa lori berisi TBS. Hal-hal yang harus dilakukan untuk mengatasi kondisi tidak aman adalah dengan cara memperlebar plat titian minimal $100 \mathrm{~cm}$. Pastikan bobot TBS yang diangkut lori tidak melebihi kapasitas untuk menjaga keseimbangan saat melintasi titian kanal. Gunakan safety boot untuk menghindari terpeleset dan gunakan sarung tangan saat menggunakan lori pengangkut buah.

Pada umumnya kegiatan pekerjaan yang dilakukan di PT. Budi Dwiyasa Perkasa berdasarkan kebiasaan, tanpa memperhatikan keselamatan dan kesehatan kerja.Perlu dilakukan sosialisasi dan pembinaan terhadap pekerja dalam melakukan aktifitas pekerjaan. Pekerja belum seluruhnya memahami akan pentingnya keselamatan dalam bekerja. Tindakan tidak aman dan kondisi tidak aman masih sering ditemukan. Berdasarkan data kecelakaan yang diperoleh pada triwulan kedua tahun 2016, terdapat lima kasus kecelakaan kerja yang terjadi akibat tertimpa pelepah karena tindakan tidak aman. Para pekerja banyak yang tidak menggunakan alat pelindung diri saat bekerja.Berbagai alasan yang diungkapkan pekerja, mulai dari keterbatasan APD sampai ketidaknyamanan bekerja jika memakai APD.Paradigma ini terjadi karena budaya keselamatan dan kesehatan kerja yang belum timbul di PT. Budi Dwiyasa Perkasa.

\section{Kesimpulan}

Dari hasil penelitian dan analisa yang telah dilakukan, dapat diambil kesimpulan sebagai berikut:
a. Berdasarkan identifikasi bahaya potensial dan penilaian risiko, 
pekerjaan yang memiliki tingkat risiko sedang adalah pada aktifitas pemotongan pelepah sawit, pemberian pupuk, pemotongan tandan buah matang dan pengangkutan buah ke TPH.

b. Bahaya potensial fisik kejatuhan pelepah pada aktifitas pemotongan pelepah sawit merupakan aktifitas yang memiliki tingkat risiko sedang dengan total nilai kemungkinan sebesar 52 dan memiliki keterkaitan dengan data kecelakaan kerja pada triwulan kedua di PT. Budi Dwiyasa Perkasa.

c. Faktor dominan yang menyebabkan kecelakaan kerja adalah perbuatan tidak aman. Pekerja tidak memperhatikan arah jatuhnya pelepah sawit pada saat melakukan pemotongan.

d. Minimnya APD yang digunakan pekerja juga berpengaruh terhadap kecelakaan kerja.

\section{Daftar Pustaka}

Undang-Undang Nomor 1 Tahun 1970, 12 Januari 1970, Keselamatan Kerja, Jakarta.

Peraturan Pemerintah Nomor 50 Tahun 2012, 12 April 2012, Penerapan Sistem Manajemen Keselamatan dan Kesehatan Kerja, Jakarta.

Peraturan Menteri Tenaga Kerja Nomor: PER.04/MEN/1987 Tahun 1987, 03 Agustus 1997, Panitia Pembina Keselamatan dan Kesehatan KerjaSerta Tata Cara Penunjukan Ahli Keselamatan Kerja, Jakarta.

Peraturan Menteri Tenaga Kerja Nomor: PER.08/MEN/2010 Tahun 2010, Alat Pelindung Diri, Jakarta.

Analisis Kecelakaan di Tempat Kerja dan PAK, Modul 19 Pengawasan Ketenagakerjaan, Departemen
Tenaga Kerja dan Transmigrasi, Jakarta.

\section{Dasar-dasar Keselamatan dan Kesehatan Kerja, Modul Pengawasan Ketenagakerjaan, Departemen Tenaga Kerja dan Transmigrasi, Jakarta.}

Hazard Identification Risk Assesment, PT. Central Pertiwi Bahari. Lampung. 